\title{
Crowdfunding - Croatian legal perspective and comparison to other sources of financing
}

KATARINA ĐURĐENIĆ, LL.M.*

\section{Article**}

JEL: G15, G18, K22, M31, O30

https://doi.org.10.3326/pse.41.2.5

\footnotetext{
* The author would like to thank the Swiss Institute of Comparative Law in Lausanne for providing her with a scholarship enabling the research for this article and to the institute staff for their hospitality during her stay there. She would also like to thank to Mr Pascal Favrod-Coune and Ms Suzana Petrović for their comments and fruitful discussions on the topic. Finally, special thanks go to Mr Thomas Kinneary Sánchez who devoted his time and knowledge to copy editing this article. The author would also like to thank to the two anonymous referees for their valuable comments and suggestions.

${ }^{* *}$ Received: June 1, 2016

Accepted: October 24, 2016
}

The article was submitted for the 2016 annual award of the Prof. Dr. Marijan Hanžeković Prize.

\section{Katarina ĐURĐENIĆ}

PhD Student at the University of Zagreb, Faculty of Law, Trg maršala Tita 14, 10000 Zagreb, Croatia e-mail: katarina.durdenic@yahoo.com ORCID iD: 0000-0002-6048-5295 


\section{Abstract}

Crowdfunding is a new way of financing ideas by raising small amounts of money from a large number of people, typically via the internet. Most countries do not have special legislation governing crowdfunding but some countries like the United States, Italy, France, the United Kingdom and Germany have amended their legislation with provisions specifically designed for crowdfunding. The first aim of this research was to examine which existing legislation could be applied to crowdfunding as well as to review whether there is a need in the Croatian system to introduce new legislation designed specifically for crowdfunding issues. The second research aim was to compare crowdfunding with other sources of financing in order to decide whether it can represent a substitute for them or only a possible complementary instrument.

Keywords: crowdfunding legislation, crowddonating, crowdrewarding, crowdinvesting, crowdlending, comparison with other sources of financing

\section{INTRODUCTION}

\subsection{DEFINITION}

Crowdfunding is a way of funding a project or venture by raising money from a large number of people who each contribute a relatively small amount, typically via the internet (Oxford Dictionaries, 2016). It usually includes a project owner (an entrepreneur, fund raiser), the internet platform that acts as a sort of intermediary through which the third participant, individuals from the crowd, give their money in order to finance a specific project developed by the project owner.

\subsection{HISTORICAL DEVELOPMENT}

Although crowdfunding tends to be presented as a new way of financing projects, it has to be clearly stated that it has a long existence. The best known historical example of crowdfunding comes from the USA and concerns the pedestal of the Statue of Liberty. The Statute itself was a gift of the French people to the American citizens, but in order to install it firmly, a pedestal had to be built, for which there were no funds available. The famous publisher Joseph Pulitzer came upon the idea of publishing an ad in his newspaper New York World in 1885, inviting all people to donate as much as they could for this purpose crying: "Let us not wait for the millionaires to give us this money. It is not a gift from the millionaires of France to the millionaires of America, but a gift of the whole people of France to the whole people of America." Some donated only one dollar but roughly 125,000 people participated in the campaign and the sum collected actually exceeded the money needed for construction. In gratitude to all the donors, New York World published their names, regardless of the size of the donation (National Park Service, 2016).

Although there are many examples similar to this, crowdfunding turned into a global phenomenon only in the 2000s and its success was determined by two important circumstances. One of them was the global financial crisis that struck 
the world in 2008 (World Bank, 2013) and made it hard for entrepreneurs to get financing through bank loans. With bank loans unavailable, other sources of financing like friends and family circles proved to be insufficient, and capital markets and business angels required more professional fund raisers, an equity gap thus being created (Lefèvre and Popescu, 2015). At the same time, world wide web 2.0 was developed and enabled better interaction and communication among its users (François, 2015) which fostered the progress of social media (MySpace, Facebook, LinkedIn) and together with that the blossoming of a whole set of websites based on a collaborative economy like Airbnb, Uber, Blablacar and Groupon. The lack of financing sources on the one hand and the possibility of communicating easily with a large number of people on the other were highly inspirational tools for people searching for money, and the crowd all of a sudden became an important investor; thus crowdfunding evolved.

\subsection{CROWDFUNDING IN NUMBERS}

Although it was perceived in the beginning as a marginal way of collecting smaller amounts of money for artistic projects, some of the most successful campaigns showed that crowdfunding could be effectively used as a financing instrument for considerable amounts as well. One of the first examples of that kind was certainly the campaign for the smart watch Pebble, which connects wirelessly to a smartphone and serves as an on-the-wrist notification centre. The campaign that started in 2012 over the internet platform Kickstarter managed to raise the amount of 10.3 million dollars whereas the target amount was only 100,000 dollars (Cunningham, 2012).

According to recent figures provided by the research firm Massolution (2015), currently in the world we have 1,250 active crowdfunding platforms. In 2014 the crowdfunding industry raised 16.2 billion dollars, more than twice as much as in 2013 when funds collected amounted to 6.1 billion dollars. The trend of steep growth continued in 2015, when 34.4 billion dollars was raised.

Compared to these world numbers, Croatian figures are still quite small. Although there are a few Croatian crowdfunding platforms (www.doniralica.hr, www.croinvest.eu, www.croenergy.eu), statistical data from foreign platforms show that Croatian fundraisers prefer to seek funding on foreign crowdfunding platforms due to the larger number of potential investors and the enhanced chances for successful financing.

By keeping track of Croatian projects on foreign crowdfunding platforms, it can be determined that 63 Croatian projects were introduced to crowdfunding in 2015, with only 23 of them managing to collect the needed funds. In total, the amount of $751,457.42$ dollars was collected from 7,673 backers. The international internet platform most popular with Croatians is Indiegogo with 47 Croatian projects in 2015 and the average amount per Croatian campaign of 10,000 dollars (Hafner, 2016). 
The palette of projects being financed through crowdfunding is very wide - it stretches from new technological gadgets and individual artistic endeavours to the financing of club transfers of professional football players (Favrod-Coune and Nafissi-Azar, 2016).

\subsection{RESEARCH GOALS}

The first aim of this research is to analyse the legal aspects of crowdfunding in Croatian law by reviewing the existing Croatian legislation and testing its application in crowdfunding in order to determine if it does cover all its aspects. In this research, the legislation of countries that introduced new legislation specifically designed for crowdfunding (USA, Italy, France, UK and Germany) will be also reviewed and in the light of this comparative approach it will be considered whether Croatian legislation needs to be amended. The second aim of this research is to compare crowdfunding with other sources of financing. The costs involved will be compared to the costs of other sources of financing and all the related advantages and disadvantages of crowdfunding will be examined in order to conclude whether it represents a substitute for the classical sources of financing or merely a complementary instrument. The greater purpose behind this research is to provide a sound legal and practical overview for project owners so that they can be confident when engaging in crowdfunding activities.

\section{CROATIAN LEGISLATION COVERING CROWDFUNDING}

The legal framework of crowdfunding could be categorized in three different approaches. The first approach is to forbid some types of crowdfunding and this approach has been used by some countries, including Japan (François, 2015). The second approach is to pass laws specifically designed for crowdfunding, adopted for instance in the USA, Italy, France, UK and Germany. The third approach is being used by the majority of countries and that is to review the existing legislation and analyse in which way it should be applied to crowdfunding. Since in Croatia there are no specific laws to either forbid or further regulate certain types of crowdfunding, the conclusion must be that Croatia has taken the third approach. In the next chapters we will analyse under which legal institutes crowdfunding should be categorized and what the implications are.

Due to the fact that crowdfunding represents a source of financing in which the main actors (project owner, crowdfunding platform and individuals from the crowd) usually act/reside in different countries, in case of a dispute, often it will be a challenge to determine the jurisdiction and applicable law (see more in Kunda, 2016). Since aspects of private international law would exceed the scope of this article, they will not be further elaborated upon and the legal perspective of crowdfunding in the chapters below will be given from the point of Croatian law.

When talking about the legal aspects of crowdfunding, it needs to be explained that crowdfunding has developed into four different types and each of them tackles different parts of legislation; they are crowddonating, crowdrewarding, crowdlending and crowdinvesting (Ancelle and Fischer, 2016). 
Crowddonating is the type of crowdfunding in which some project is financed by donations of people who do not expect anything in return. Although the motives of backers are charitable, which is why this type of crowdfunding is described by some authors as altruism (Gierczak et al., 2016), it is important to note that donations may also fund for-profit enterprises (Bradford, 2012).

\subsubsection{Gift contract}

Legal qualification of this type of crowdfunding is rather easy since donation and gift are synonyms (Friganović, 2011) and donation can be therefore qualified as a gift contract that is regulated in the Croatian Law on Obligations. According to article 479 of the Croatian Law on Obligations, a gift contract is concluded when a donor commits to give a thing or other property right to a person who accepts the gift without doing anything in return. The legal provisions of the Law on Obligations define what is considered to be a gift, in what form the contract needs to be concluded, and in which cases the gift can be revoked, and so on, but all these stipulations are of minor significance in the crowdfunding sense of donation.

\subsubsection{Tax issues}

However, categorisation as donation is very important from the perspective of tax law, for the person receiving the donation as much as for the donor. According to article 6, 7 and 13 of the Law Concerning the Financing of Units of Local Government and Regional Self-Government, individuals and legal entities that in the Republic of Croatia receive money as a gift, need to pay 5\% of the donated sum as taxes. Since from chapter 1.3 of this article it can be seen that Croatian project owners tend to collect funds on foreign internet platforms, this means that they are not receiving a gift in the Republic of Croatia and therefore these provisions will not be applied to them. However, if the donation takes place through a Croatian internet platform, these provisions do apply but it is to be noted that according to article 14 of the same act, gifts tax is not paid in certain cases; for example, if a gift is received from a spouse or linear relatives or if it is given for the purposes laid out by separate regulations.

From the perspective of donor, it is to be noted that according to article 36, paragraph 12 of Croatian Income Tax Act, a taxpayer may have his/her personal allowance increased by gifts in kind and in cash given in Croatia and transferred to giro accounts of associations and other persons engaged in cultural, educational, scientific, health-care, humanitarian, sports-related or religious activities pursuant to special regulations, up to $2 \%$ of the taxpayer's income for which the annual tax return was submitted and the annual income tax assessed in the previous year. A similar provision exists also in article 7, paragraph 7 of Croatian Profit Tax Act. In these cases, money donated through Croatian internet platforms could be used in certain cases in order to deduct taxes to be paid, resulting in an additional motivation for donors to participate in crowdfunded campaigns. 
In reward-based crowdfunding, project owners usually determine amounts that are to be paid and in return, depending on the amount, they provide a certain reward to the donor. This reward can for example be a t-shirt, badge or some other memorabilia but it can be also a product for whose production itself the collected money has been used. Therefore, some authors (Bradford, 2012) tend to divide this type of crowdfunding into two different types: one which uses souvenir-like objects representing a pure reward model of crowdfunding, whereas the other one can be called a pre-purchase model of crowdrewarding. This distinction is quite important since these different subcategories of reward-based crowdfunding are indeed covered by different aspects of legislation.

\subsubsection{Pure reward based crowdfunding}

An example of reward based crowdfunding is to be found in the case of the Goulash Disco Festival of Balkan music, which took place from 3-6 September 2013 on the Island of Vis in Croatia and was entirely funded by donations through the internet platform Ulule (Ulule, 2013). Depending on the size of donation (6-10,870 dollars or more) the donor in return got different kinds of rewards ranging from having his or her name listed on the website of the Festival, getting a postcard from the festival or the status of a god materialized in a statue to be built on the beach.

Regarding the legal aspects of pure reward-based crowdfunding, everything that was written for crowddonating is also relevant. According to article 489 of the Croatian Law on Obligations such cases involve mutual gifts according to which if it is agreed that the person accepting a gift gives a gift in return, the gift exists only for the value in excess of such donation. This is to say that only the part of a donor's gift that exceeds the value of the gift (memorabilia) received will be regarded as a gift. As for the first part of the "gift" that has a counter-value in the memorabilia received, one can see this legal relationship as a sale purchase agreement regulated under articles 376-473 of Croatian Law on Obligations. However, due to the specific circumstances of this deal, the real counter value of the donated souvenir cannot be estimated (consider the aforementioned example of god status materialized in a statue) since it has a rather sentimental value; therefore it is better to treat the whole deal as a gift contract in both directions.

\subsubsection{Pre-purchase model}

A nice Croatian example of reward-based crowdfunding that partially uses a prepurchase model is a project called Enfojer that conducted a campaign on the internet platform Indiegogo in 2013. Enfojer is presented as an "old school darkroom for smartphones," namely it is a portable enlarger that enables you to develop real photographs from digital images saved on your phone. In this campaign, the first 100 donors (described as Early Herd Special) receive an Enfojer kit for the discounted price of 250 dollars (Indiegogo, 2013). 
Although the name pre-purchase suggests that the legal transaction behind this crowdfunding model is to be categorized under sale-purchase agreement, we have to carefully examine if that is the final classification. Obvious answers are not always correct, for it has to be taken into account that crowdfunded projects very often entail innovative products as seen in the above example of Enfojer. The products cannot be produced easily and are often dependent on the creative talent of precise creators who themselves cannot be easily replaced either. Therefore, although under article 380, paragraph 3 of the Croatian Law on Obligations, an object of a share purchase agreement can be a thing that does not yet exist, under article 591, paragraph 3 of the same law where the parties to the contract have the particular value of the producer's work in mind, an agreement will always constitute a contract for work that is regulated in articles 590-619 of the Croatian Law on Obligations.

Having that in mind, one needs to beware of the implications of such categorisation, especially concerning the right to terminate the contract and liability for product defects. According to article 597 of Croatian Law on Obligations, the producer needs to finish a product in the time that was determined by the contract. Usually, in the case of the pre-purchase model of crowdfunding, it is clearly stated on the internet platform when the product can be expected. If during the production it becomes obvious that the producer is not following an agreement and that he is not doing what he should, under article 598 of Croatian Law on Obligations the orderer can warn him about it and give him a certain deadline to comply, and if he does not do it, the orderer can terminate the contract and claim for damages. The delivered products are not to be seen as "test examples" that do not have to satisfy any standards; the producer bears full responsibility that its products really function as was agreed. If the product shows certain defects, under article 604, paragraph 1 and 608, paragraph 1 of Croatian Law on Obligations, the orderer must examine the product as soon as possible and without delay inform the producer about the defect claiming for the repair within the defined deadline. If the producer refuses to repair a product due to extensive costs, the orderer can claim a price reduction or termination of contract, and in both cases he has the right to claim damages under article 608, paragraph 3 of Croatian Law on Obligations. Under article 605 of the Law on Obligations, the producer is liable for hidden defects as well but only if they are noticed within 2 years from the delivery of the product. In the event of a substantial defect, under article 609 of the Law on Obligations, the orderer can terminate a contract without asking for repair and claim damages. It is also to be stated that the orderer can, under article 619 of Croatian Law on Obligations terminate the production agreement as long as the product is not finished, but in this case he has to pay a remuneration to the producer, which will be reduced by the costs that the producer did not have and for the profit that the producer made or deliberately omitted.

In cases where the parties to the contract do not have a particular value of the producer's work in mind, the contract could be classified as a sale purchase agreement that is regulated by articles 376-473 of Croatian Law on Obligations. 
However, having in mind the definition of crowdfunding put forward in chapter 1.1 of this article, where it is stated explicitly that the purpose of crowdfunding is funding of a project or venture, it seems that neither of the possible categorizations of the pre-purchase model into the group of existing nominated contracts of the Law on Obligations matches completely. Indeed, this purpose is not even mentioned in a contract for works or a sale purchase agreement, which leads us to the conclusion that the pre-purchase model of crowdfunding would be best understood as a specific form of contract that falls under the category of innominate contracts; the key principle of the Law on Obligations is party autonomy (Gorenc, 2005) which means that parties are free to determine what kind of contract they are concluding, who their partners are and what the content of the contract will be. In the case of nominate contracts, the Law on Obligations makes it easier for the parties to contract since the law provides them with the description of their duties and obligations in case they do not determine them on their own.

In a case in which the parties wish to conclude a contract that cannot be categorized under any of the nominated contracts, they can determine the content of the contract on their own. In this case however, they are bound by the restrictions of article 2 of the Law on Obligations that requires that parties regulate their obligations in compliance with the Constitution of the Republic of Croatia, its mandatory laws and the morals of the society.

\subsection{CROWDLENDING}

Crowdlending is a type of crowdfunding where the borrowers through an internet platform find lenders who lend them money in return for interest. Although the Croatian platform Croinvest states that it also offers this type of crowdfunding, on its website there is no proof that such a model has ever been used. It may be possible that some Croatian entities have used this model on foreign platforms, but because websites providing crowdlending usually require registration before their databases can be accessed, it is not possible to check this easily. However, in order to explain this model better, we can use the example of the prominent US-American internet platform Prosper that operates this crowdfunding model.

Using Prosper, borrowers can borrow 2,000-35,000 dollars depending on the duration of the loan, which can be 3 or 5 years, and lenders get their money back together with a certain interest. Before listing a loan on their website, Prosper credit checks applications to ensure that the borrowers can afford the loan and to ensure that they meet all the eligibility criteria. This listing needs to attract a sufficient number of investors in order to reach a requested loan amount. If investors commit a sufficient amount of funds to the loan, the borrower will receive the requested loan. 


\subsubsection{Loan contract}

The relationship that is created between the borrower and the lender in this type of crowdfunding can be categorized as a loan contract that is regulated in articles 499-508 of the Law on Obligations. In a loan contract, the lender is obligated to lend a certain amount of the money to the borrower, who commits to return the same amount of the money. Under article 500 of the Law on Obligations interest is not obligatory but in the case of crowdlending it is usually agreed upon. Since the crowdlending platform acts merely as an intermediary, it is not to be treated as a party to the contract (Crnić, 2012).

What is interesting to have in mind when submitting this relationship to the category of a classical loan contract is that according to article 506 of the Law on Obligations, the borrower can renounce the contract up until he receives the money, but in this case the lender can claim for damages, if any. In the context of crowdfunding it is particularly interesting to see what happens if a loan is not used for the purpose that was agreed upon. Usually, on crowdlending sites you can find touching stories on how the money is going to be used. Article 508 of the Law on Obligations regulates a loan with a purpose in a way that in case the purpose of the loan has been determined in the loan contract, the lender can terminate the contract if the borrower uses the money for another purpose. So, if the purpose is determined in the contract, it presents an essential element of the contract (Gorenc, 2005). However, if the loan is paid in time with the interest agreed upon, it is very likely that the lenders will not wish to terminate it.

\subsubsection{Banking and payment services regulation}

In the case of crowdlending it is necessary to analyse whether the internet platform provides banking services and therefore needs to be regulated under the Croatian Credit Institutions Act. According to article 7 of this act, banking services include receiving deposits or other returnable funds from the public and approving credits from these funds, for its own account. In the case of crowdlending platforms, it cannot really be said that it is approving credits for its own account but more likely it is to be seen as an intermediary between a borrower and a lender that conclude a loan contract; therefore, it is not to be treated as a credit institution that would require approval from Croatian National Bank according to article 56 of the Credit Institutions Act.

It is to be noted that this means that money paid via crowdlending platforms is not secured by the deposit insurance system run by State Agency for Deposit Insurance and Bank Resolution under Deposit Insurance Act. According to article 7, paragraph 1 of this act, deposits up to 100,000 euros are protected in the event of a credit institution's bankruptcy.

However, depending on the structure of interaction between the borrowers, lenders and crowdlending platform, it may be possible that the crowdlending platform will perform one of the payment services from article 3 of Act on Payment Trans- 
actions and therefore would need to acquire an appropriate licence from the regulatory authority.

\subsection{CROWDINVESTING}

Crowdinvesting is also known under the term equity crowdfunding and it represents a type of crowdfunding in which people provide money in return for a share in the profit from the business that is to be funded with that money. The way in which this share is transmitted is very different and depending on that, it will impinge on totally different legislative issues.

\subsubsection{Stocks in joint-stock company}

If the future business of the crowdfunded company is organized as a joint-stock company in which every investor that participated in the crowdfunding campaign will receive stock in return, one needs to take into account the provisions of the Croatian Commercial Companies Act that regulate joint-stock companies.

\subsubsection{Prospectus}

Besides that, when offering shares to the public, which is what actually happens in this sort of crowdfunding, one also needs to take into account the provisions of the Croatian Capital Markets Act. According to article 354 of the Capital Markets Act, a public offer of securities is not allowed in Croatia unless the prospectus has been previously approved by Croatian Financial Services Supervisory Agency is published. The prospectus is to be made according to Commission regulation 809/2004 of 29 April 2004 implementing Directive 2003/71/EC of the European Parliament and of the Council as regards information contained in prospectuses as well as the format, incorporation by reference and publication of such prospectuses and dissemination of advertisements. This document needs to provide an investor with basic information about the issuer and the securities offered, but in practice this basic information stretches to around 400 pages (Đurđenić, Simić and Krunić, 2016).

However, it is to be noted that according to article 342, paragraph 1, point 7 of the Capital Markets Act the prospectus is not required in the case of offers that in a 12-month period do not exceed the amount of 5,000,000 euros. Since the amounts of the Croatian crowdfunded campaigns according to the available information do not exceed this amount, prospectus regulation will not be triggered. We have to consider that on 30 November 2015 the European Commission published a proposal for a regulation supplementing Directive 2003/71/EC of the European Parliament and of the Council with regard to regulatory technical standards for approval and publication of the prospectus and dissemination of advertisements and amending Commission Regulation 809/2004. According to article 1, paragraph 3, point d) of this proposal, the amount of 5,000,000 euros is to be raised to $10,000,000$ euros but the member states will have the possibility of setting it at 500,000 euros. If Croatia decides to set a lower amount at which the publication of a prospectus becomes obligatory, there is a greater chance that some of the crowdfunded campaigns will need a prospectus. 


\subsubsection{Investment services regulation}

Besides a prospectus, when offering shares to the public, internet platforms need to take into account special regulations considering investment services. That is, the reception and transmission of orders in relation to shares is considered to be one of the investment services under article 5, paragraph 1, point 1 of Croatian Capital Markets Act and investments services under article 6 of the same act can only be offered by investment firms or credit institutions that have obtained special approval from regulating authorities such as the Croatian Financial Services Supervisory Agency or Croatian National Bank. In order to obtain such approval, companies need to satisfy very strict organizational requirements and their management also needs to get special licences. The fee payable to the Croatian Financial Services Supervisory Agency for the approval of the stated investment service alone costs 10,000 kunas according to article 4, paragraph 3, point 1 of Regulation on the type and the amount of fees and administrative charges of the Croatian Financial Services Supervisory Agency. Due to the high starting costs, it is expected that crowdinvesting activities including the offer of shares in Croatia will be operated by already existing investment firms.

\subsubsection{Shares in limited company}

If one wants to finance a business by collecting money in return for shares in a limited company, the provisions of the Commercial Companies Act that regulate a foundation and management of such company have to be taken into account. Since according to article 385, paragraph 1 of the Commercial Companies Act, shares in a limited company cannot be expressed in the form of securities, the current prospectus regime will not be triggered. It is to be noted that in some countries public offers of shares in a limited company also require a prospectus that needs to be approved by a regulatory authority; such an obligation exists for instance in Germany, according to article 1, paragraph 2, and article 6 of the Investments Act. No such obligation exists in Croatia for now and therefore it would be possible to offer shares in a limited company by public offer in Croatia without a prospectus approved by a regulatory authority. However, it is to be noted that even in these cases, a certain form of informative memorandum containing basic information on the company would be highly recommended because it would positively contribute to investor protection.

\subsubsection{Silent partnerships}

A convenient form of financing business by crowdinvesting is also possible in the form of silent partnership which is regulated under articles 148-158 of the Commercial Companies Act. When compared to limited companies, silent partnerships are much easier to enter into since they require a contract that is not subject to a particular form and that is why they are easier to conclude by means of distant communication like the internet. In the case of the limited companies, according to article 387, paragraph 1 of the Commercial Companies Act a limited company is founded by a contract that needs to be signed in the form of a notarial act or in the form of a private document confirmed by a notary. The same form is required 
under article 412, paragraph 3 of the Commercial Companies Act for the transfer of a share in the limited company. Since these forms require the personal presence of an investor and entail certain costs, silent partnerships are a more favourable form of investment in crowdfunding. Under article 148, paragraph 1 of the Commercial Companies Act, a silent partnership is established by the contract according to which one person (the silent partner) invests some property value into the company of another person (the entrepreneur) and that is how he gets a right to participate in the profit and loss of the entrepreneur.

Although the silent partner does not have full informational rights comparable to those of the shareholder in a limited company, according to article 150 of the Commercial Companies Act, he has a right to examine financial statements and demand copies of them in order to check if they are correct and he has a right to get clarifications if needed. Exactly these supervisory rights of the silent partner constitute an important point of distinction between a silent partnership and profit participating rights. That is, the profit of the company can also be granted by a company to a person that invests some property value into the company in return for a right to participate in the profits (Barbić, 2013). However, a holder of a profit participating right does not have supervisory powers over the entrepreneur.

Supervisory powers of a silent partner distinguish a silent partnership from the loan contract as well. This distinction is however rather obvious since in the case of the loan contract, it is interest that is agreed upon, and not a share in profit, as in the case of a silent partnership (Gorenc et al., 2008).

\subsubsection{Alternative investment fund}

If an internet platform collects money from investors with the aim of investing in some company, there is a concern that by doing so it performs the activity of an alternative investment fund which is defined under article 3, point 2 of the Alternative Investment Funds Act as an investment fund founded with the purpose of raising funds through public or private offer and of investing these funds in different types of property in line with a predetermined strategy and investment aim, exclusively for the benefits of the shareholder in such an alternative investment fund. Although the law does not define a strategy or investment aim, these terms suggest that one needs to have the possibility to choose among various investments according to one's strategy and investment aim and actively manage such decisions. In the case of crowdfunding, the internet platform invests according to the orders of crowdfunders into the given company and it does not have discretionary powers in doing so; therefore, it does not constitute an alternative investment fund (Saria and Stocker, 2015; Hooghiemstra and De Buysere, 2016).

\section{COMPARATIVE LEGAL ANALYSIS}

Although most of the countries in the world have not introduced new legal rules for crowdfunding, some countries have decided to do so. In the paragraphs that follow, we will be briefly outlining the legislation of the following countries USA, Italy, France, UK and Germany, which have passed laws specifically 
designed for crowdfunding. As will be seen, in these legislative actions, crowddonating and crowdrewarding have not been caught up by the new legislation, the scope of legislation being mostly limited to crowdinvesting and crowdlending.

\subsection{USA}

On 5 April 2012 President Obama signed the Jumpstart Our Business Startups Act or JOBS Act, with the intention of encouraging the funding of US small businesses by easing various securities regulations. On 30 October 2015, additional rules regarding equity crowdfunding were introduced in Title III of the act. It is to be noted that before the JOBS Act it was not allowed to offer securities in the USA without complying with the burdensome 1933 Act Registration and Disclosure Requirements and 1934 Act Periodic Reporting Requirements (Hazen, 2012). Before explaining the outlines of JOBS Act, it should first be stressed that term security under American law has a much wider scope than in European law. Namely, under US law, the term security does not only include stocks or other traditional investment vehicles, but also interests in partnerships and limited liability companies that fall within the scope of the investment contract under the so-called Howey test (Bradford, 2012). Since the costs of compliance with the financial regulations were very high for smaller companies, the JOBS act created a special regime that enables emerging growth companies (issuers that had total annual gross revenues of less than 1,000,000,000 dollars) to offer securities under certain conditions.

In this way they can raise amounts up to $1,000,000$ dollars per year via crowdfunding platforms that need to be registered with the US Securities and Exchange Commission (SEC) as a broker/dealer or as a funding portal. They also must register with one or more self-regulatory organizations like the Financial Industry Regulatory Authority (FINRA). The obligation to register as a broker/dealer actually provides a substantial advantage to this industry (Cunningham, 2012) since it can push existing financial actors into new business models. Under the JOBS Act, investors are limited in two ways: first of all they cannot invest more than $5 \%$ or 2,000 dollars of their yearly net income if their net income is less than 100,000 dollars (if it is higher, they can spend $10 \%$ of income) and second, crowdfunded securities may not be transferred by the purchaser of such securities during the one year period beginning on the date of purchase, unless some special conditions apply. Although this trading restriction has a strong impact on the liquidity of these securities, the intention behind it was to prevent manipulation in the form of "pumping up" the price of a security by posting untrue or exaggerated information (Cunningham, 2012).

\subsection{ITALY}

With Law Decree number 179 ("Further urgent measures for economic growth of the country") dated 18 October 2012 that was converted into law on 17 December 2012 , Italy has received a legal act that regulates equity based crowdfunding. The law was additionally clarified by a regulation number 18592 from 26 June 2013. 
With the new legislation in force only innovative start-up companies (that must satisfy several conditions to be treated as such) can raise amounts up to 5,000,000 euros per year via an Italian equity crowdfunding platform, which is significantly more than in the USA (Lerro, 2014). The management of such web platforms is reserved for investment firms and banks authorized to provide investment services as well as for companies entered in a special register managed by Commissione Nazionale per le Società e la Borsa (Consob).

In order for the offer on the crowdfunding platform to be effective, at least $5 \%$ of the financial instruments offered have to be subscribed by professional investors, bank foundations or innovative start-up incubators. In this way legislators ensured more credibility for crowdfunded offers because it is expected that professional investors, when compared with simple investors, perform more serious due diligence before investing into something. The web platform must take care that the collected funds for each offer are deposited in an escrow account in the issuer's name at the bank or investment firm.

It is exactly prescribed which information on the offer must be available at the crowdfunding platform and it must include for example the information on the risk of losing the entire investment and the risk of illiquidity and information on the withdrawal right. Namely, the crowdfunding platform must grant non-professional investors a withdrawal right from the subscription, free of any charge, within 7 days from the order. It is to be noted that withdrawal rights in this form are usually not granted in investment contracts so this presents an additional protection for the investors.

\subsection{FRANCE}

Unlike the USA and Italy which have decided to regulate only crowdinvesting, on 1 October 2014 in France legislation that deals with crowdinvesting, crowdlending and crowddonating came into force (Clasen, 2015; Ancelle and Fischer, 2016).

Until that date, all offers of securities with a total amount of more than 100,000 euros were subject to the obligation to publish a prospectus. According to new regulations offers of securities through a crowdfunding platform up to the total amount of 1,000,000 euros are exempt from the obligation to publish a prospectus. However, the issuer still has to provide some information such as project description, management structure, existing financial reports or estimated calculations, explanation of the costs that will be charged to an investor, and information on the risk assessment. Besides classic investment advisors that can deal with all sorts of securities, advisors on participative investments are introduced as a new category of intermediaries that can only deal with shares and fixed rate bonds and cannot accept funds from investors (except for their own fees).

In the field of crowdlending, according to the new French legislation it is possible for legal persons and natural persons that undertake some professional activity or 
need a loan in order to fund their studies to borrow funds up to 1,000,000 euros with a maximum duration of 7 years. Only natural persons can be lenders in the case of interest-bearing loans and their participation is limited up to an amount of 1,000 euros per project. Regulatory, crowdlending platforms have been labelled as intermediaries in participative investments. Intermediaries in participative investments cannot perform transfer of funds between lenders and borrowers unless they obtain the status of a payment establishment.

Both advisors on participative investments and intermediaries in participative investments have to comply with certain rules of good conduct.

\subsection{UNITED KINGDOM}

In the UK crowdinvesting and crowdlending have been explicitly regulated by Policy statement 14/4 that was put forward by the Financial Conduct Authority (FCA) and came into force on 1 April 2014. This kind of regulation means that platforms that offer crowdinvesting and crowdlending have to comply with both the specific regulation and also the general rules that apply to firms regulated by FCA (Ancelle and Fischer, 2016).

With regard to crowdinvesting, new consumer protection rules are created according to which firms may only make direct offer promotions to retail consumers who meet certain criteria: those who take regulated advice, those who qualify as high net worth or sophisticated investors, or those who confirm they will invest less than $10 \%$ of their net assets in this type of security. Their rules also require firms to check whether customers understand the risks if they do not take regulated advice (FCA, 2015).

With regard to crowdlending, the rules that apply make sure that consumers interested in lending to individuals or businesses have access to clear information; in this way they can assess the risk and understand who will ultimately borrow the money. Additionally, some core consumer protection requirements apply to firms operating in this market. For example, client money must be protected and firms must meet minimum capital standards. Finally, the FCA requires that firms that run these platforms have resolution plans in order to ensure that in the event of the platform collapsing, loan repayments will continue to be collected and returned to those who lent money (FCA, 2015).

\subsection{GERMANY}

Although one would expect Germany to be a pioneer in the regulation of crowdfunding, the Retail Investor's Protection Act that regulates crowdfunding in Germany was adopted only on 23 April 2015 and came into force on 10 July 2015, three years after the US regulation.

With the new legislation, if an offer does not exceed 2.5 million euros, there is no need to publish a prospectus, but the offer needs to consist of certain investment 
types such as profit-participating loans, subordinated loans and other similar financing forms and investments. These investments can only be offered by platforms that offer investment consulting and investment brokerage. Despite the absence of a prospectus, issuers still need to prepare an investment information sheet that must contain essential information about the investment and a warning that the investment is associated with significant risks and can result in the total loss of the money invested.

When investing, natural persons are limited to an amount of 1,000 euros per issuer; however, if they can prove they have at least 100,000 euros of freely available assets, they can invest up to 10,000 euros per issuer.

Although crowdfunding associations deem this legislative action to be positive (European Crowdfunding Network, 2015), some authors criticize it for several reasons, especially because of the fact that the prospectus exemption does not relate to all types of investments and all types of securities (Klöhn and Hornuf, 2015).

\subsection{EUROPEAN UNION}

At the EU level there is still no legislation that is designed specifically for crowdfunding, but some doubts whether crowdfunding needs to be regulated were publicly raised in 2013. That year the European Commission opened a 3-month public consultation under the title Crowdfunding in Europe? Exploring the added value of potential EU action. The ultimate objective of this consultation was to gather data about the needs of market participants and to identify the areas in which there is a potential added value in EU action to encourage the growth of this new industry, either through facilitative, soft-law measures or legislative action (European Commission, 2013). Following the consultation process, on March 27, 2014 the European Commission published a Communication on Crowdfunding in which it proposes to promote industry best practices, raise awareness and facilitate the development of a quality label, closely monitor the development of crowdfunding markets and national legal frameworks and regularly assess whether any form of further EU action - including legislative action - is necessary (European Commission, 2014).

With the purpose of achieving these goals, in June 2014 the European Commission founded the European Crowdfunding Stakeholder Forum - an expert group of high level representatives of associations of concerned stakeholder groups and national authorities that regularly meets and helps the Commission explore future actions in this field.

In May 2016 the European Commission published its report on the EU crowdfunding sector together with a press release in which it was stated that there was no strong case for an EU level framework at this point, but that developments in the sector would remain under review (European Commission, 2016). 


\section{COMPARISON WITH OTHER SOURCES OF FINANCING}

In the following chapters crowdfunding will be primarily compared with bank loans and capital markets as other sources of financing, but the relation to other sources of financing may be involved as well. Advantages and disadvantages will be reviewed from the perspective of project owners but not investors.

\subsection{ADVANTAGES}

\subsubsection{Wider scope of potential investors}

If you want to ask for a credit from a bank in Croatia, you are limited to 27 credit institutions that have such a licence in Croatia (Croatian National Bank, 2016). When searching for funding in capital markets, you are also limited to investors that actively engage there. However, with crowdfunding you gain access to all the ordinary people that use the internet, have different interests and can also emotionally relate to the project that is being presented and decide to invest in it. People want something that they cannot buy at every store and they enjoy thinking that they have helped finance something truly special (Flebbe, 2015). Besides, crowdfunding has high multiplication potential (François, 2015) which some authors describe as "herd behaviour" (Hornuf and Schwienbacher, 2015) so financing goals can be reached very quickly.

It is also to be noted that the scope of potential investors is widened also through the lifting of geographical barriers (Grabner, 2015). With crowdfunding platforms that operate worldwide, a local project can successfully be funded by people who live on the other side of the world, as evidenced by 23 Croatian projects having been successfully financed in 2015 through foreign crowdfunding platforms (Hafner, 2016).

\subsubsection{Simple administrative processing}

Only a look at the list of documents that banks in Croatia usually require for entrepreneurial loans can be demotivating - registration document, tax statements for previous years, excerpts from income and expenses lists, list of long-term property, confirmation on debt to tax authority, bank account statements, confirmation from credit register (Erste\&Steiermärkische Bank d.d., 2016). So, before (or after) coming to the bank, an entrepreneur that wants funding for a certain project needs to invest additional time to collect all the needed documents. The administrative burden with crowdfunding will depend on the internal rules of each platform, though generally in crowdfunding portals the focus is on the project itself and no additional administrative tasks are required from a project owner. This makes it easy for him to process the financing request. Besides, banks or business angels usually tend to perform certain due diligence before agreeing to financing and that takes time so crowdfunding presents usually a faster way of financing (Lefèvre and Popescu, 2015). 


\subsubsection{Market sounding}

Probably one of the biggest advantages of crowdfunding is its ability to test the market while at the same time raising funds for a certain project. This advantage is most visible with new products that are yet to be developed and produced by the help of crowdfunding. The more backers a crowdfunding campaign for such products has, the more potential buyers of the finished products can be expected (Golić, 2016). Therefore, crowdfunding is a great way to test out new ideas and weed out bad business ideas at an early stage before a considerable amount of money is wasted in their investment (Pope, 2011).

\subsubsection{Networking}

Obviously, crowdfunded projects have more visibility than projects that are financed by bank loans or capital markets. Besides easier market research as described in the previous chapter of this article, this circumstance allows the project owners to network more effectively with other entrepreneurs with similar or complementary projects. Thus, networking proves to be one of the most important motivators for crowdfunders (Čondić-Jurkić, 2015).

In order to show the potential of networking in the example, let us go back to the project Enfojer referred in chapter 2.2.2 of this article. The campaign for "Old school darkroom for smartphones" will most likely attract the producers of photo paper who in turn offer their collaboration with the project owners. It could also get the attention of specialised stores of photo equipment that might want to include the new product in their range.

\subsubsection{Wisdom of crowds}

Crowdfunding platforms usually provide an effective communication channel that enables project owners to exchange information with investors. In this way, as explained in previous paragraphs of this article, crowdfunders have an opportunity to get feedback from market participants, to meet potential new partners but to improve their projects as well. Described as wisdom of crowds (Baumann, 2014; Golić, 2016) or crowdsourcing (Stucki, 2014), the ability of a crowd to provide effective solutions through online consultation is not to be underestimated. One of the creators of the first Croatian computer game that was financed through crowdfunding (Legends of Dawn) mentioned that one of the motives behind choosing crowdfunding as a way of financing the new game Wave of Darkness was to have direct contact with the buyers who can give them suggestions (Hafner, 2015).

\subsection{DISADVANTAGES}

Although crowdfunding bears certain risks for investors such as risk of fraud, lack of transparency, possible dilution of ownership and illiquidity (Čondić-Jurkić, 2015; Vedantam, 2016), which will not be further elaborated upon in this article, it is not to be forgotten that project owners also have to deal with some disadvantages when engaging in this source of financing. 


\subsubsection{Marketing efforts}

Administrative burdens like collecting the set of necessary documentation for bank loans or drafting a prospectus for capital markets characterise other sources of financing. However, crowdfunding challenges project owners to engage more intensively in marketing activities when preparing their campaign (Grabner, 2015). Usually, on crowdfunding platforms a certain project is presented through a video that has to be sufficiently interesting, informative and motivating. Besides a video, one has to actively advertise the project in social media in order to profit from the multiplication potential of crowdfunding.

Many good projects fail only due to the fact that project owners do not invest enough effort in marketing. A good Croatian example of that is the computer game Red Solstice that first tried to receive funding in 2012 via the platform Indiegogo. Of the requested 10,000 dollars they managed to get only 3,000 dollars. In 2014 they repeated the campaign via the platform Kickstarter requesting 50,000 dollars and this time they succeeded. In the second campaign they used a more sophisticated PR campaign that was run by professionals and they maintained a high level of interaction with the backers of the game (Šojer, 2014).

Good communication forms part of marketing efforts and is crucial for the success of a crowdfunding campaign (Gross, 2014). Through interaction with project owners, backers obtain better information and they get a feeling that somebody is fully involved in the project. According to the research of Reservoir Funds, 86\% of project owners regularly communicate on social networks (Arnaud des Abbayes, 2015), either by posting comments or uploading photos or videos related to the campaign. This can be very time consuming since it means that one has to stay online and alert during the whole day, which is not always easy to combine with an everyday schedule.

\subsubsection{Intellectual property exposure}

As a consequence of the wider scope of potential investors comes a wider scope of persons who can steal the business idea. In certain cases, crowdfunded campaigns for innovative products feature the characteristics of a certain product and provide enough information which enables other persons to realise the idea. The misuse of an innovative idea can be prevented by protecting intellectual property in time but usually the development of the idea depends on the financial means that are to be collected by campaign. Therefore, at an early stage, the information on the product is not yet specific enough to go through patent procedure. However, it is to be noted that the finalisation of the product strongly depends on the skills and experience of a developer so not every project can be successfully completed by any other person besides the initial project owner.

\subsubsection{Risking future funding}

Failure to collect funds via crowdfunding can create bad marketing for the project. In the case of a bank loan, if a bank refuses to finance an entrepreneur, he can easily go to another bank that does not have to know about the decision of the first 
bank. In the case of a project that fails to raise means by crowdfunding, the whole internet population knows about it and can form a negative opinion on the project based on the fact that it did not manage to get funding. So, other means of financing or upcoming projects of the same developer can be negatively influenced by this experience.

\section{COSTS OF CROWDFUNDING}

In the following paragraphs the costs and potential gains for investors will not be analysed but the costs will be calculated from the perspective of project owners.

\subsection{PLATFORM COSTS}

The average costs of crowdfunding are not easy to determine since they will depend on the type of crowdfunding platform and internal rules of the platform. However, in order to get a better overview of the costs, these will be presented with the example of three crowdfunding platforms - Indiegogo, the most used foreign platform by Croatian project owners that offers both the crowddonating and crowdrewarding models; Prosper, one of the world's most successful crowdlending platform and Seedrs, one of the best known crowdinvesting platforms.

Indiegogo, which attracts the most Croatian project owners, charges a fee of 5\% on all collected funds. In addition to the fees of the platform, as is stated on their website, one has to reckon with the fees of payment processors such as Pay Pal and credit card companies that amount to $3-5 \%$ of the raised amount (Indiegogo, 2016). It is to be noted that for now Croatian crowdfunding platforms that offer crowddonating do not charge fees and therefore they should be more appealing to Croatian project owners, but due to the wider scope of investors on foreign platforms, project owners still prefer to list their projects there.

When compared with the transparency of fees for crowddonating and crowdrewarding, the costs of crowdlending were not so easy to find out. Namely, in order to get the exact interest rates from crowdlending platforms, one usually needs to provide a platform with the information on the employment status and annual income, as well as information on real estate property and possible mortgages. The possible rate will then depend on the rating given by the platform based on the information collected and the terms of loan. However, Prosper publicly announced a scale of possible interest rates that range from $5.32-31.90 \%$ (Prosper on Rates, 2016). Beside the interest rate, with Prosper one needs to reckon with a closing fee, a percentage of money that will be deducted from the amount that is to be paid as a loan on the borrower's account. This percentage can range from $0.5-4.95 \%$ (Prosper on Fees, 2016).

Seedrs, one of the most well known crowdinvesting platforms, has a very clear administrative fee that is fixed to $7.5 \%$ of the total funds that are raised, but if there is only one new investor on the project the fee is reduced to $3.75 \%$ of the raised funds (Seedrs, 2016). This shows that the network of Seedrs investors is very 
limited and not so dynamic, thus every new investor in the network is highly appreciated.

In order the better to show the costs of crowdfunding, they are presented in the table below on the example of raising 10,000 euros, calculated with the lowest possible fees, and in case of a crowdlending with a repayment time of 3 years.

TABLE 1

Estimated costs of crowdfunding platforms in EUR on the example of 10,000 euros

\begin{tabular}{|c|c|c|c|c|c|c|c|}
\hline & $\begin{array}{l}\text { Interest } \\
\text { rate } \\
\text { percentage }\end{array}$ & $\begin{array}{l}\text { Interest } \\
\text { rate } \\
\text { amount } \\
(\mathrm{A})^{*}\end{array}$ & $\begin{array}{l}\text { Platform } \\
\text { fee } \\
\text { percentage }\end{array}$ & $\begin{array}{l}\text { Platform } \\
\text { fee } \\
\text { amount } \\
\text { (B) }\end{array}$ & $\begin{array}{l}\text { Payment } \\
\text { fee } \\
\text { percentage }\end{array}$ & $\begin{array}{l}\text { Payment } \\
\text { fee } \\
\text { amount } \\
\text { (C) }\end{array}$ & $\begin{array}{c}\text { Total } \\
(\mathrm{A}+\mathrm{B}+\mathrm{C})\end{array}$ \\
\hline Indiegogo & 1 & 1 & 5 & 500 & 3 & 300 & 800 \\
\hline Prosper & 5.32 & $1,082.38$ & 0.50 & 50 & 1 & 1 & $1,132.38$ \\
\hline Seedrs & 1 & 1 & 3.75 & & 1 & 1 & 375 \\
\hline
\end{tabular}

*Based on annuity repayment.

Source: Calculation of the author, Indiegogo, Prosper, Seedrs.

\subsection{MARKETING COSTS}

As explained in chapter 4.2.1 of this article, marketing is very important for the success of crowdfunding campaigns. Although many project owners tend to do the marketing of the project on their own, if there are bigger goals one needs to think about hiring a professional marketing expert to take charge of determining a strategy, creating a promotional video, booking advertisements, etc.

The costs of marketing services are hard to determine since they will depend on the scope of the services included and the prestige of the marketing agency that has been hired. However, according to the estimate of one American digital marketing agency, costs for marketing efforts are estimated at 15,000 dollars (Command Partners, 2016).

\subsection{COMPARISON WITH BANK LOANS}

Since all information is not shown on banks' websites, in order to arrive at the costs that banks usually charge for personal and entrepreneurial loans, for the purpose of this research, an inquiry was sent to all banks in Croatia requesting information on the interest rates and additional costs that are charged in the case of a loan in the amount of about 10,000 euros with a repayment time of 3 years. The amount of the loan has been chosen based on the fact that in 2015 the average amount that was asked for by Croatian project owners on foreign crowdfunding platforms was 10,000 dollars (Hafner, 2016). Out of 27 credit institutions in Croatia that were sent the inquiry, a response was received from 6 of them. Only 2 responses included the numerical information about the interest rates and incurred costs while other banks replied in standardized form that all the available information can be found on their website and/or that each request is processed individually and therefore the exact calculation may vary. 
By comparing the received information with the available information on the websites of banks in Croatia, it can be concluded that entrepreneurial loans are usually issued with an interest rate of $7-8.5 \%$ and an administrative charge of $1 \%$ of the claimed amount. It is also to be noted that in certain cases other costs (like public notary's costs) may be incurred. In order to better show the sum of costs that arises on an entrepreneurial bank loan of 10,000 euros, we show them in the table below, calculated with the repayment period of 3 years. Again, for the purpose of calculation, the lowest interest rate is used.

\section{TABle 2}

Estimated costs of bank loan on the example of 10,000 euros

\begin{tabular}{|c|c|c|c|c|c|}
\hline $\begin{array}{l}\text { Repayment } \\
\text { time }\end{array}$ & $\begin{array}{l}\text { Interest } \\
\text { rate } \\
\text { percentage }\end{array}$ & $\begin{array}{c}\text { Interest } \\
\text { amount in } \\
\text { EUR (A)* }\end{array}$ & $\begin{array}{c}\text { Administrative } \\
\text { charges } \\
\text { percentage }\end{array}$ & $\begin{array}{c}\text { Administrative } \\
\text { charges amount } \\
\text { in EUR (B) }\end{array}$ & $\begin{array}{c}\text { Total } \\
\text { in EUR } \\
(\mathbf{A}+\mathbf{B})\end{array}$ \\
\hline 3 years & 7 & $1,431.55$ & 1 & 100 & $1,531.55$ \\
\hline
\end{tabular}

*Based on annuity repayment.

Source: Calculation of the author, Veneto banka d.d., Sberbank d.d.

If the costs of bank loans are compared with the costs of crowdfunding, it can be concluded that the total costs of a bank loan go beyond the costs of a crowdfunding platform. However, it is to be noted that hiring an external marketing expert in crowdfunding campaigns significantly increases the costs of crowdfunding pushing them far beyond the costs of bank loans.

It seems that banks have already recognized the competitive potential of crowdfunding so some of them have started to get shares in crowdfunding platforms. One such example is the case of Berliner Volksbank that in 2013 acquired a share in the German crowdinvesting platform Bergfürst. The experts that participated in the study of St. Gallen University on the development of crowdfunding predict that by the year $202010 \%$ of banks in the German-speaking area will actively cooperate with crowdfunding platforms and that $5 \%$ of them will have their own crowdfunding platforms (Blohm et alia, 2015).

\subsection{COMPARISON WITH CAPITAL MARKETS}

Analysis of the costs that may occur when raising money in capital markets would require extensive analyses of the clearing company charges, regulated market fees, financial intermediaries' rates, administrative fees and so on that go beyond the framework of this research. Therefore, in order to show the costs that arise, the data from some of the prospectuses that have been published in Croatia in 2015 have been used to analyse these costs, more specifically ones that had a clear indication of the amount of the funds that have been raised and a clear presentation of the costs. The texts of prospectuses have been derived from the list of approved prospectuses that can be found on the website of the Croatian Financial Services Supervisory Agency (Hanfa, 2016). These costs are shown in the table below. 
TABLe 3

Costs of raising money in capital markets with example of some issues of securities from 2015

\begin{tabular}{|c|c|c|c|c|}
\hline Issuer & $\begin{array}{c}\text { Funds raised } \\
\text { in millions of } \\
\text { HRK }\end{array}$ & $\begin{array}{c}\text { Date of } \\
\text { prospectus } \\
\text { approval }\end{array}$ & $\begin{array}{c}\text { Amount of costs } \\
\text { in millions of } \\
\text { HRK }\end{array}$ & $\begin{array}{c}\text { Costs as } \\
\text { percentage of } \\
\text { funds raised }\end{array}$ \\
\hline $\begin{array}{l}\text { Hrvatska poštanska } \\
\text { banka d.d. }\end{array}$ & 550 & 30.10 .2015 & 6.2 & 1.13 \\
\hline $\begin{array}{l}\text { Tankerska next } \\
\text { generation d.d. }\end{array}$ & 104.3 & 16.10 .2015 & 1.2 & 1.15 \\
\hline Podravka d.d. & Up to 510 & 19.6 .2015 & 4 & 0.78 \\
\hline Luka Rijeka d.d. & 300 & 19.6 .2015 & 2.3 & 0.77 \\
\hline Petrokemija d.d. & 253.04 & 6.3 .2015 & 0.9 & 0.36 \\
\hline Granolio d.d. & 94.02 & 27.2.2015 & 2 & 2.13 \\
\hline HTP Korčula d.d. & Up to 66.02 & 13.2 .2015 & 0.23 & 0.35 \\
\hline $\begin{array}{l}\text { Tankerska next } \\
\text { generation d.d. }\end{array}$ & app. 241.1 & 16.1 .2015 & app. 7.3 & 3.03 \\
\hline Average & & & & 1.21 \\
\hline
\end{tabular}

Source: Calculation of the author, Croatian Financial Services Supervisory Agency.

It should be noted that it is hard to compare the cost of crowdfunding with the costs of raising money in capital markets since crowdfunding has usually been used by Croatians in order to collect smaller amounts of money (average 10,000 dollars as stated in Hafner, 2016), whereas the prospectuses used in this research served to raise considerable funds (as seen in table 3 ). However, when the average percentage of costs in capital markets $(1.21 \%)$ is compared to the percentage of costs that crowdfunding platforms charge $(3.75 \%$ and more as showed in paragraph 5.1. of this article), it can be concluded that the costs of crowdfunding are significantly higher. Still, it has to be taken into account that costs in capital markets are based on economy of scale. Only some of the fixed costs that appear in the issuing of securities, such as a fee for the approval of prospectus that is to be paid to the Croatian Financial Services Supervisory Agency (according to article 4, paragraph 2 of Regulation on the type and amount of fees and administrative charges of the Croatian Financial Services Supervisory Agency) amounts to almost 4,000 euros which goes beyond all the stated costs on the crowdfunding example from chapter 5.1 of this article.

\section{CONCLUSION}

All types of crowdfunding can be categorized under certain existing law institutes as elaborated upon in chapter 2 of this article. Therefore, no new laws specifically to regulate crowdfunding are needed.

It has to be taken into account that the countries that undertook legislative actions concerning crowdfunding aimed them mostly at crowdlending and crowdinvesting and not on the other types of crowdfunding. In these countries a smaller offer of securities already constituted a need to publish a prospectus and the new legis- 
lation first of all aimed to allow securities offer without burdensome prospectus regime for higher amounts as well. In Croatia, the threshold that triggers the obligation to publish a prospectus is set to more than 5,000,000 euros and as crowdfunding campaigns usually have goals far below this amount, they are not affected by prospectus regulation.

When compared with other sources of financing, crowdfunding offers numerous advantages such as a wider scope of potential investors, simple processing, market sounding, networking and the possibility to gain input from the crowd. In terms of basic costs it also proves to be more affordable than bank loans. It can be hardly compared with capital markets since they usually serve to collect significant means and their costs are based on the economy of scale. Therefore some fixed costs in capital markets go far beyond the costs of a usual crowdfunding campaign, although the percentage of costs in the funds raised seems to be much lower in capital markets.

However, when compared with other sources of financing, crowdfunding in order to be successful requires significant marketing efforts. If a project owner does not possess the skills and experience in marketing, he or she has to reckon with additional costs of external marketing experts that can seriously raise the costs of a campaign and make it more expensive than other sources of financing. Therefore, crowdfunding cannot totally replace existing sources of financing.

Still, the examples presented through this article show that crowdfunding has been mostly used to finance creative projects that have problems with traditional funding. Therefore, it should be seen as a supplement to the existing financing models, and can be used when these models fail. It seems that banks have also recognized crowdfunding as a profitable alternative so some of them have started to achieve gains by actively supporting crowdfunding platforms.

\section{Disclosure statement}

No potential conflict of interest was reported by the author. 


\section{REFERENCES}

1. Ancelle, J. and Fischer, P., 2016. Regulation of Crowdfunding Activities in Switzerland: Where do we Stand? Available at: <www.jusletter.ch $>$.

2. Arnaud des Abbayes, 2015. Le crowdfunding, un nouveau marché? Paris: A. Franel.

3. Barbić, J., 2013. Pravo društava, Knjiga druga, Društva kapitala. Zagreb: Organizator.

4. Baumann, S., 2014. Crowdinvesting im Finanzmarktrecht. Zürich: Schulthess.

5. Blohm, I. [et al.], 2015. Crowdfunding 2020: Komplement oder Substitut für die Finanzindustrie. Norderstedt: Books on Demand.

6. Bradford, C. S., 2012. Crowdfunding and the Federal Securities Laws. Columbia Business Law Review, (1), pp. 1-150

7. Clasen, B., 2015. Crowdfunding in Frankreich. RIW, (6), pp. 344-350.

8. CNB, 2016. Kreditne institucije. Available at: <http://www.hnb.hr/temeljnefunkcije/supervizija/popis-kreditnih-institucija $>$.

9. Command Partners. 2016. How Much Does it Cost to Run a Crowdfunding Campaign? Available at: <http://commandpartners.com/blog/how-much-doesit-cost-to-run-a-crowdfunding-campaign $>$.

10. Čondić-Jurkić, I., 2015. Crowdfunding - što znamo o alternativnom izvoru financiranja?. Notitia - časopis za održivi razvoj, (1), pp. 71-83.

11. Crnić, I., 2012. Zakon o obveznim odnosima. Zagreb: Organizator.

12. Croatian Financial Services Supervisory Agency (Hanfa). 2016. Popis odobrenih prospekata. Available at: <http:/www.hanfa.hr/HR/nav/239/popis-odobrenih-prospekata.html>.

13. Cunningham, W.M., 2012. The jobs act: crowdfunding for small businesses and startups. New York: Apress. doi: 10.1007/978-1-4302-4756-2

14. Đurđenić, K., Krunić, V. and Simić S., 2016. Prospekt vrijednosnih papira gdje smo i kamo idemo. Pravo u gospodarstvu, (2), pp. 281-305.

15. Erste\&Steiermärkische Bank d.d., 2016. Potrebna dokumentacija. Available at: <https://www.erstebank.hr/hr/Poslovni_subjekti/Mali_poduzetnici/Platni_ promet/Potrebna_dokumentacija $>$.

16. European Commission, 2013. Press Release: Crowdfunding in the EU-exploring the added value of potential EU action. Available at: $<$ http://europa. eu/rapid/press-release_IP-13-906_en.htm?locale=en>.

17. European Commission, 2014. Press Release: Commission roadmap to meet the long-term financing needs of the European economy. Available at: $<\mathrm{http}$ :/ europa.eu/rapid/press-release_IP-14-320_en.htm?locale=en>.

18. European Commission, 2016. Press Release: Capital Markets Union: Commission supports crowdfunding as alternative source of finance for Europe's start-ups. Available at: <http://europa.eu/rapid/press-release_IP-16-1647_en. htm?locale $=$ en $>$.

19. European Crowdfunding Network, 2015. Germany Adopts Crowdfunding Rules. Available at: <http://eurocrowd.org/2015/04/28/germany-adopts-crowdfunding-rules/>. 
20. Favrod-Coune, P. and Nafissi-Azar, S., 2016. Le crowdfunding comme source alternative de financement des clubs professionnels de football. CEDIDAC 2016/1.

21. FCA, 2015. A review of the regulatory regime for crowdfunding and the promotion of non-readily realisable securities by other media. Available at: $<\mathrm{https}$ :// www.fca.org.uk/static/documents/crowdfunding-review.pdf>.

22. Flebbe, M., 2015. Crowdfunding als alternative Finanzierungsform: durch die Methode der Schwarmfinanzierung von der Idee zum Massenprodukt. Hamburg: Diplomica.

23. François, B., 2015. "Le Financement participatif par souscription de titres: Étude en droit compare" in: Le Fur, V. Le cadre juridique du crowdfunding: analyses prospectives. Paris: Société de législation comparée.

24. Friganović, M., 2011. Oporezivanje darovanja u Republici Hrvatskoj. Računovodstvo i porezi, (6), pp. 82-99.

25. Gierczak, M. M. [et al.], 2016. "Crowdfunding: Outlining the New Era of Fundraising" in: D. Brüntje and O. Gajda. Crowdfunding in Europe: state of the art in theory and practice. Cham: Springer International Publishing.

26. Golić, Z., 2016. "Crowdfunding: Waker of Small Hidden Insignificant Funds?" in: D. Assadi. Strategic approaches to successful crowdfunding. Hershey: Business Science Reference. doi: 10.4018/978-1-4666-9604-4.ch012

27. Gorenc, V. [et al.], 2008. Komentar Zakona o trgovačkim društvima. Zagreb: RRiF.

28. Gorenc, V., 2005. Komentar Zakona o obveznim odnosima. Zagreb: RRiF.

29. Grabner, C., 2015. Crowdfunding: a new financing and investment alternative. Saarbrücken: AV Akademikerverlag.

30. Gross, J., 2014. Crowdfunding: an equity financing instrument. München: Grin.

31. Hafner, H., 2015. Nakon LoD, zagrebački studio predstavio Wave of Darkness na Kickstarteru. Available at: <http://www.crowdfunding.hr/wave-of-darkness-2985>.

32. Hafner, H., 2016. U Hrvatskoj do sada prikupljeno 10 milijuna kuna. Available at: <http://www.crowdfunding.hr/infografika-crowdfunding-u-hrvatskoj2015-3376>.

33. Hazen, T. L., 2012. Crowdfunding or Fraudfunding? Social Networks and the Securities Laws - Why the Specially Tailored Exemption Must be Conditioned on Meaningful Disclosure. North Carolina Law Review, 90, pp. 1735-1770.

34. Hooghiemstra, N. and De Buysere K., 2016. "The Perfect Regulation of Crowdfunding: What Should the European Regulator Do?” in: D. Brüntje and O. Gajda. Crowdfunding in Europe: state of the art in theory and practice. Cham: Springer International Publishing. doi: 10.1007/978-3-319-18017-5_10

35. Hornuf, L. and Schwienbacher, A., 2015. Funding Dynamics in Crowdinvesting. Research Papers in Economics, 9/15. Available at: $<$ https://www.uni-trier. de/fileadmin/fb4/prof/VWL/EWF/Research_Papers/2015-09.pdf $>$.

36. Indiegogo, 2013. Old School Darkroom for Smartphones. Available at: <https:// www.indiegogo.com/projects/enfojer-old-school-darkroom-for-smartphones\#/>. 
37. Indiegogo, 2016. How much does Indiegogo cost? Available at: <https://support.indiegogo.com/hc/en-us/articles/204456408-How-much-does-Indiegogo-cost-Fees-Pricing $>$.

38. Klöhn, L. and Hornuf, L., 2015. Die Regelung des Crowdfunding im Regierungsentwurf des Kleinanlegerschutzgesetzes: Inhalt, Auswirkungen, Kritik, Änderungsvorschläge. Der Betrieb, 68(1), pp. 47-53.

39. Kunda I., 2016. "Jurisdiction and Applicable Law in Crowdfunding" in: Ž. Primorac [et al.]. 16th International Scientific Conference on Economic and Social Development - "The Legal Challenges of Modern World”, pp. 253-263.

40. Lefèvre, F. and Popescu B. F., 2015. Le crowdfunding à la française. Paris: Presses des Mines.

41. Lerro, A. M., 2014. Italian Equity Crowdfunding Legislation: Laws and Regulations. Roma: Lerro \& Partners.

42. Massolution, 2015. 2015 CF Crowdfunding Industry. Available at: <http:// www.massolution.com/ $>$.

43. National Park Service, 2016. Joseph Pulitzer. Available at: < https://www.nps. gov/stli/learn/historyculture/joseph-pulitzer.htm>.

44. Pope N. D., 2011. Crowdfunding Microstartups: It's Time for the Securities and Exchange Commission to Approve a Small Offering Exemption. University of Pennsylvania Journal of Business Law, 13(4), pp. 101-129.

45. Prosper, 2016. Fees. Available at: <https://www.prosper.com/help/contextual/ fees/ $>$.

46. Prosper. 2016. What are loan interest rates and estimated lender returns? Available at: <https://prosper.zendesk.com/hc/en-us/articles/203328845-Whatare-loan-interest-rates-and-estimated-lender-returns- $>$.

47. Saria, G. and Stocker, F., 2015. Unternehmensanleihen und Crowdfunding: Rechtliche und wirtschaftliche Grundlagen und Aspekte. Wien: Manz.

48. Seedrs, 2016. Getting Started. Available at: <https://www.seedrs.com/raise>.

49. Šojer, T., 2014. Hrvatska igra Red Solstice: 'Propali' na Indiegogou, uspjeli na Kickstarteru. Available at: $<$ http://www.netokracija.com/red-solstice-kickstarter-74097>.

50. Stucki, D., 2014. Financer une entreprise par le crowdfunding: les nouvelles règles du crowdinvesting. Paris: Eyrolles: Revue Banque éd.

51. Ulule, 2013. Goulash Disko Festival. Available at: <http://de.ulule.com/goulash2013/>.

52. Vedantam, L., 2016. "Toward a Typology of Crowdfunding Motivation” in: D. Assadi. Strategic approaches to successful crowdfunding. Hershey: Business Science Reference.

53. World Bank, 2013. Crowdfunding's Potential for the Developing World. Available at: $<$ https://openknowledge.worldbank.org/handle/10986/17626 License: CC BY 3.0 IGO>. 


\section{LEGAL SOURCES (ORIGINAL NAMES IN BRACKETS)}

\section{CROATIA}

Act on Payment Transactions (Zakon o platnom prometu, Official Gazette 133/09 and 136/12)

Alternative Investment Funds Act (Zakon o alternativnim investicijskim fondovima, Official Gazette 16/13 and 143/14)

Capital Markets Act (Zakon o tržištu kapitala, Official Gazette 88/08, 146/08, 74/09, 54/13, 159/13, 18/15 and 110/15)

Commercial Companies Act (Zakon o trgovačkim društvima, Official Gazette 111/93, 34/99, 121/99, 52/00, 118/03, 107/07, 146/08, 137/09, 125/11, 152/11, $111 / 12,68 / 13$ and $110 / 15)$

Credit Institutions Act (Zakon o kreditnim institucijama, Official Gazette 159/13, $19 / 15$ and $102 / 15)$

Deposit Insurance Act (Zakon o osiguranju depozita, Official Gazette 82/15)

Income Tax Act (Zakon o porezu na dohodak, Official Gazette 177/04, 73/08, $80 / 10,114 / 11,22 / 12,144 / 12,120 / 12,125 / 13,148 / 13,83 / 14,143 / 14$ and $136 / 15)$,

Law Concerning the Financing of Units of Local Government and Regional SelfGovernment (Zakon o financiranju jedinica lokalne i područne (regionalne) samouprave, Official Gazette 117/93, 33/00, 73/00, 59/01, 107/01, 117/01, 150/02, 147/03, 132/06, 26/07, 73/08, 25/12, 147/14 and 100/15)

Law on Obligations (Zakon o obveznim odnosima, Official Gazette 35/05, 41/08, $125 / 11$ and $78 / 15)$

Profit Tax Act (Zakon o porezu na dobit, Official Gazette 177/04, 90/05, 57/06, $146 / 08,146 / 08,80 / 10,22 / 12,148 / 13$ and 143/14)

Regulation on the type and the amount of fees and administrative charges of Croatian Financial Services Supervisory Agency (Pravilnik o vrsti i visini naknada i administrativnih pristojbi Hrvatske agencije za nadzor financijskih usluga, Official Gazette 3/16)

\section{FRANCE}

Law number 2014-1053 on participative financing (Décret n. 2014-1053 relatif au financement participative, Official Gazette 215/14)

\section{GERMANY}

Investments Act (Vermögensanlagengesetz from 6 December 2011 (BGB1. I S. 2481), last time revised by Act from 18 July 2016 (BGBl. I S. 1666))

Retail Investor Protection Act (Kleinanlegerschutzgesetz, BGBl. I 2015, S. 1114)

\section{ITALY}

Law Decree number 179 "Further urgent measures for economic growth of the country" (Decreto Legge n. 179 "Ulteriori misure urgenti per la crescita del Paese”, Official Gazette 294/12) 
Policy Statement 14/4 The FCA's regulatory approach to crowdfunding over the internet, and the promotion of non-readily realisable securities by other media Available at <https://www.fca.org.uk/publication/policy/ps14-04.pdf $>$ [Accessed 8 April 2016]

\section{USA}

Jumpstart Our Business Startups Act (H.R. 3606)

Securities Act of 1933 (15 U.S.C. $§ 77$ a et seq.)

Securities Act of 1934 (15 U.S.C. $\S 78$ a et seq.)

EU

Commission regulation 809/2004 of 29 April 2004 implementing Directive 2003/71/EC of the European Parliament and of the Council as regards information contained in prospectuses as well as the format, incorporation by reference and publication of such prospectuses and dissemination of advertisements, 2004 O.J. L 149/1

Proposal for a Regulation supplementing Directive 2003/71/EC of the European Parliament and of the Council with regard to regulatory technical standards for approval and publication of the prospectus and dissemination of advertisements and amending Commission Regulation (EC) No 809/2004, C(2015) 8379 final 